\title{
PENGARUH KOMPETENSI, BUDAYA ORGANISASI, DAN PEMBELAJARAN, TERHADAP KINERJA ANGGOTA STUDI KAUSAL DI SKATEK O21 LANUD HALIM PERDANAKUSUMA
}

\author{
Kadarwati \\ Dosen Tetap S2 Unsurya \\ kadarwatika@yahoo.com
}

\begin{abstract}
ABSTRAK
Penelitian ini untuk membuktikan pengaruh variabel Kompetensi $\left(X_{i}\right)$, Budaya Organisasi $\left(X_{2}\right)$ dan Pembelajaran $\left(X_{3}\right)$ terhadap Kinerja (Y). Sampel penelitian 100 orang Anggota yang diambil secara acak sederhana dari populasi terjangkau dan berkarakter sama yaitu yang berpangkat Bintara tamtama, dari jumlah 173 Anggota di Skadron Teknik 021 Lanud Halim Perdanakusuma. Penelitian ini menggunakan pendekatan kuantitatif, dan menggunakan metode survei, pada November 2017. Teknik analisis data penelitian, menggunakan Analisis Berdasarkan hasil analisis penelitian: Jalur (Path Analysis).

1) Terdapat pengaruh langsung secara positif dan signifikan variabel Kompetensi $\left(X_{I}\right)$ terhadap variabel Pembelajaran $\left(X_{3}\right)$, secara parsial sebesar $17 \%$.

2) Terdapat pengaruh langsung secara positif dan signifikan variabel Budaya Organisasi $\left(X_{2}\right)$ terhadap variabel Pembelajaran $\left(X_{3}\right)$, secara parsial sebesar $46,02 \%$.

3) Terdapat pengaruh langsung secara positif dan signifikan variabel Kompetensi $\left(X_{1}\right)$ terhadap variabel Kinerja (Y), secara parsial sebesar 13,61\%.

4) Terdapat pengaruh langsung secara positif dan signifikan variabel Budaya Organisasi $\left(X_{2}\right)$ terhadap variabel Kinerja $(Y)$, secara parsial sebesar 26,7\%.

5) Terdapat pengaruh langsung secara positif dan signifikan variabel Pembelajaran $\left(X_{3}\right)$ terhadap variabel Kinerja (Y), secara parsial sebesar 17,58\%.
\end{abstract}

Kata Kunci : Kompetensi, Budaya Organisasi, Pembelajaran, dan Kinerja

\section{PENDAHULUAN}

\section{A. Latar Belakang Masalah}

Tentara Nasional Indonesia Angkatan Udara (TNI AU) sebagai suatu organisasi pertahanan yang memiliki tugas sebagai pelaksana pertahanan negara matra udara menjadikan keselamatan pelaksanaan tugas menjadi prinsip-prinsipnya. Dihadapkan pada tugas TNI Angkatan Udara sebagaimana yang diamanatkan dalam pasal 10 Undang-
Undang RI Nomor 34 Tahun 2004 tentang Tentara Nasional Indonesia, tugas TNI Angkatan Udara adalah melaksanakan tugas TNI matra udara di bidang pertahanan, menegakan hukum dan menjaga keamanan wilayah udara yurisdiksi nasional sesuai dengan ketentuan hukum nasional dan hukum internasional yang sudah diratifikasi, melaksanakan tugas TNI dalam pembangunan dan pengembangan kekuatan 
matra udara, serta melaksanakan pemberdayaan wilayah pertahanan udara.

Untuk mendukung kelancaran tugas TNI Angkatan Udara maka disusunlah organisasi yang saling bersinergi dan saling terkait dalam menjalankan bidang tugasnya yaitu bidang tugas operasi, logistik dan personel. Dalam penelitian ini peneliti akan membahas khusus bidang logistik. Dalam bidang logistik dilaksanakan pemeliharaan atau perawatan terhadap kesiapan alat utama sistem senjata (Alutsista) maupun non alat utama sistem senjata (Non Alutsista) untuk mendukung kegiatan operasi TNI Angkatan Udara secara optimal dengan menciptakan iklim kerja yang selalu peka terhadap perkembangan ilmu pengetahuan, lingkungan, teknologi dan tantangan yang dihadapi.Tantangan tugas yang harus dihadapi pada masa yang akan datang adalah kemampuan anggota personel dalam menanggulangi keterbatasan sumber daya, penguasaan ilmu pengetahuan, teknologi dan informasi yang diaplikasikan dalam pengoperasian Alutsista yang dipelihara. Kemampuan ini harus dibina dan ditingkatkan secara terus menerus sehingga tercipta keseimbangan kondisi antara kemajuan ilmu pengetahuan kerja, aplikatif, teknologi serta rekayasa kerja yang digunakan untuk menangani berbagai permasalahan yang timbul dengan kemampuan yang dimiliki guna meningkatkan kinerja anggota personel pemeliharaan.

Skadron Teknik 021 sebagai satuan pemeliharaan tingkat sedang pesawat terbang dibawah Pangkalan Udara Halim Perdanakusuma menjadi salah satu aspek penting. Kinerja anggota personel pemeliharaan yang optimal sangat besar perannya dalam upaya mendukung pelaksanaan tugas TNI Angkatan Udara yang mengedepankan keselamatan terbang sebagai prinsip yang utama yaitu tercapainya Zero Accident. Saat ini Skadron Teknik 021 mempunyai tugas melaksanakan pemeliharaan pesawat di jajaran Pangkalan Udara Halim Perdanakusuma sampai dengan tingkat

\section{B. Identifikasi Masalah}

Berdasarkan latar belakang masalah di atas, maka dapat diidentifikasikan permasalahan yang berkaitan dengan kinerja anggota Skadron Teknik 021 meliputi:

1. Kompetensi berpengaruh terhadap pembelajaran,

2. Budaya Organisasi berpengaruh terhadap pembelajaran,

3. Kompetenasi berpengaruh terhadap kinerja,

4. Budaya Organisasi berpengaruh terhadap kinerja, 
5. Pembelajaran berpengaruh terhadap kinerja.

Dari faktor yang berpengaruh terhadap kinerja, ada beberapa faktor yang berpengaruh dominan terhadap kinerja anggota Skadron Teknik 021, maka perlu dilakukan penelitian faktor-faktor yang berpengaruh terhadap kinerja anggota Skadron Teknik 021 terkait pekerjaan seharihari yaitu faktor Kompetensi, Budaya Organisasi dan Pembelajaran.

Oleh karena itu dalam penelitian ilmiah ini, yang diteliti adalah variabel Kompetensi, variabel Budaya Organisasi, variabel Pembelajaran dan variabel Kinerja.

Dalam proses pencapaian kinerja, banyak faktor yang dapat diupayakan oleh Skadron Teknik 021, diantaranya adalah meningkatkan kompetensi yang berguna untuk peningkatan pencapaian hasil secara berkelanjutan, untuk meningkatkan kinerja individual dalam rangka mencapai kinerja organisasi.

\section{Pembatasan Masalah}

Berdasarkan identifikasi permasalahan di atas, maka penelitian ini akan dibatasi pada variabel yang diduga berpengaruh kuat dan langsung terhadap kinerja anggota.Variabelvariabel tersebut adalah variabel kompetensi, budaya organisasi dan variabel pembelajaran terkait pengaruhnya terhadap kinerja anggota.
Adapun anggota dimaksud adalah seluruh anggota Skadron Teknik 021 Lanud Halim Perdanakusuma.

\section{Rumusan Masalah}

Berdasarkan pembatasan masalah yang telah diuraikan diatas, maka permasalahan dalam penelitian ini dapat dirumuskan sebagai berikut:

1. Apakah Kompetensi berpengaruh terhadap Pembelajaran Anggota Skadron Teknik 021 ?

2. Apakah Budaya Organisasi berpengaruh terhadap Pembelajaran Anggota Skadron Teknik 021 ?

3. Apakah Kompetensi berpengaruh terhadap Kinerja Anggota Skadron Teknik 021?

4. Apakah Budaya Organisasi berpengaruh terhadap Kinerja Anggota Skadron Teknik 021 ?

5. Apakah Pembelajaran berpengaruh terhadap Kinerja Anggota Skadron Teknik 021 ?

\section{E. Kegunaan Hasil Penelitian}

1. Penelitian ini dapat memberikan masukan untuk pengembangan ilmu pengetahuan. Penelitian ini dapat memberikan masukan untuk pengembangan ilmu pengetahuan, khususnya pengembangan di bidang ilmu Sumber Daya Manusia (SDM) dan dapat menjadi dasar penelitian selanjutnya.

2. Penelitian ini juga dapat digunakan sebagai masukan informasi bagi Skadron Teknik 
021 dalam meningkatkan kualitas Sumber Daya Manusia dan untuk meningkatkan kinerja Anggota personel yang secara langsung akan meningkatkan pencapaian kinerja Skadron Teknik 021 untuk pengembangan dan peningkatan kualitas organisasi dalam rangka mendukung tugas TNI Angkatan Udara.

\section{DESKRIPSI TEORETIK, KERANGKA BERPIKIR \& PENGAJUAN HIPOTESIS}

\section{A. Deskripsi Teoretik}

Teori model integratif dari perilaku organisasi menurut Colquitt, Lepine dan Wesson (2011:9) sebagai pedoman penelitian, diilustrasikan pada gambar 2.1., sebagai berikut:

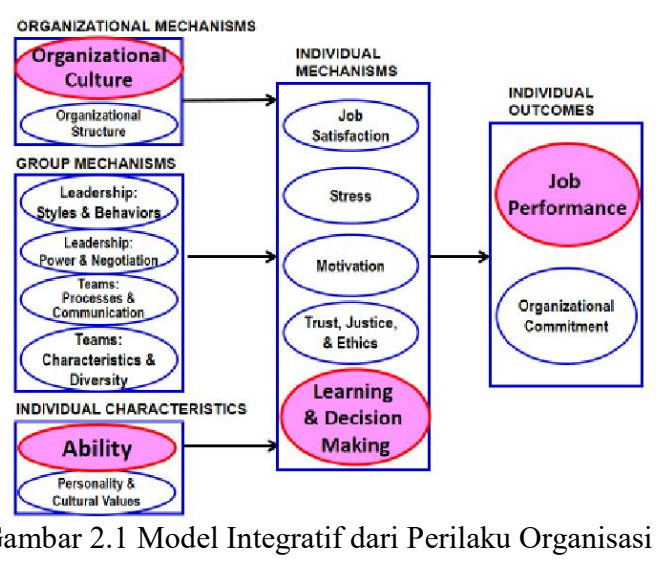

\section{Kinerja}

\section{a. Pengertian Kinerja}

Colquitt, Lepine dan Wesson, (2011: 35) mengungkapkan bahwa: "Kinerja secara formal didefinisikan sebagai nilai dari serangkaian perilaku karyawan yang memberikan kontribusi, baik secara positif maupun negatif terhadap pencapaian tujuan organisasi"

Robbins dan Judge (2009:61) menyatakan bahwa: "produktivitas adalah ukuran kinerja yang mencakup efektivitas dan efisiensi, sedangkan efektivitas yaitu pencapaian tujuan-tujuan, dan efisiensi yaitu rasio hasil efektif dengan masukan yang dibutuhkan untuk mencapainya.

Soekidjo (2009:124) merumuskan "kinerja adalah hasil kerja yang dapat ditampilkan atau penampilan kerja seorang karyawan, dengan demikian kinerja seorang karyawan dapat diukur dari hasil kerja, hasil tugas, atau hasil kegiatan dalam kurun waktu tertentu".

Hadari (2008:234) mendefinisikan "kinerja adalah hasil pelaksanaan suatu pekerjaan, baik bersifat fisik/material maupun non-fisik/non-material".

\section{b. Dimensi Kinerja}

Mondy (2008:213) menetapkan aspek kriteria kinerja karyawan yang paling umum meliputi: 1) sifat, 2)perilaku, 3)kompetensi, 4)pencapaian tujuan, dan 5) potensi perbaikan

Dessler (2008:295) menyebutkan pertimbangan mendasar dalam mengukur kinerja karyawan meliputi dimensi sebagai berikut: 1)kualitas pekerjaan, 2) kuantitas pekerjaan, 3)kesesuaian waktu pekerjaan, 4)pengembangan kompetensi dan 5)pencapaian tujuan. 
Mathis dan Jackson (2006: 378) mengungkapkan bahwa: "Kinerja karyawan yang umum untuk kebanyakan pekerjaan meliputi elemen sebagai berikut: 1)kuantitas dari hasil, 2) kualitas dari hasil, 3) ketepatan waktu dari hasil, 4) kehadiran, dan 5)kemampuan bekerjasama.

\section{c. Manajemen Kinerja}

Menurut Amstrong yang dikutip oleh Wibowo (2012:8), Manajemen Kinerja sebagai sarana untuk mendapatkan hasil yang lebih baik dari organisasi, tim, dan individu dengan cara memahami dan mengelola kinerja dalam suatu kerangka tujuan, standar, dan persyaratan-persyaratan atribut yang disepakati.

Mondy (2008:210) mengungkapkan bahwa: "Manajemen Kinerja adalah proses berorientasi tujuan yang diarahkan untuk memastikan bahwa proses-proses keorganisasian ada pada tempatnya untuk memaksimalkan produktivitas para karyawan, tim dan akhirnya organisasi.

\section{d. Sintesis Kinerja}

Dari uraian di atas, maka yang dimaksud dengan Kinerja adalah hasil pekerjaan seseorang dalam pelaksanaan tugas pekerjaannya dengan indikator: kuantitas hasil, kualitas hasil, ketepatan waktu, pencapaian tujuan, dan kemampuan bekerjasama.

\section{Kompetensi}

a. Pengertian Kompetensi
Chambers (1995:2) menyebutkan sinonim ability, adalah capacity, power, talent, skill, competence, dan capability.

Colquitt, LePine dan Wesson (2011:339) menyatakan bahwa: "Kompetensi menunjuk kepada kapabilitas orang yang relatif stabil untuk melaksanakan suatu jangkauan aktivitas yang berbeda tetapi terkait.

Robbins dan Judge

(2009:79) mendefinisikan Kompetensi berarti kapasitas seorang individu untuk melakukan beragam tugas dalam suatu pekerjaan. Kompetensi adalah sebuah penilaian terkini atas apa yang dapat dilakukan seseorang.

Wibowo (2012:324) mengungkapkan bahwa: Kompetensi adalah suatu kemampuan untuk melaksanakan atau melakukan suatu pekerjaan atau tugas yang dilandasi atas keterampilan dan pengetahuan serta didukung oleh sikap kerja yang dituntut oleh pekerjaan tersebut. Dengan demikian kompetensi menunjukkan keterampilan atau pengetahuan yang dicirikan oleh profesionalisme dalam suatu bidang tertentu sebagai sesuatu yang terpenting, sebagai unggulan bidang tersebut.

\section{b. Dimensi Kompetensi}

Wibowo (2012:325-326), menjelaskan: "terdapat lima karakteristik kompetensi, meliputi: 1) motif, 2) sifat, 3) konsep diri, 4)pengetahuan, dan 5)keterampilan.

Kreitner dan Kinicki (2008:139) mengungkapkan, kompetensi yang 
diperlukan untuk melakukan berbagai pekerjaan, yang digunakan sebagai dasar untuk keputusan tentang mempekerjakan, pelatihan, promosi, dan masalah sumber daya manusia lainnya, kompetensi yang diinginkan, meliputi: 1) pengetahuan, 2) sikap, 3)ketrampilan, 4) komunikasi lisan, 5)inisiatif, 6) ketegasan, 7) toleransi, 8)pemecahan masalah, 9) kemampuan beradaptasi, dan 10)ketahanan.

\section{c. Strata Kompetensi}

Wibowo (2012:334) mengungkapkan: Kompetensi dapat dipilah-pilah menurut stratanya. Kompetensi dapat dibagi menjadi:

1) Core competencies, merupakan kompetensi inti yang dihubungkan dengan strategi organisasi, sehingga harus dimiliki oleh semua karyawan dalam organisasi.

2) Managerial competencies, merupakan kompetensi yang mencerminkan aktivitas manajerial dan kinerja yang diperlukan dalam peran tertentu.

3) Functional competencies, merupakan kompetensi yang menjelaskan tentang kemampuan peran tertentu yang diperlukan dan biasanya dihubungkan dengan keterampilan professional atau teknis.

\section{d. Pengaruh Kompetensi terhadap Pembelajaran}

Noe et al., (2008:276) mengungkapkan faktor-faktor yang mempengaruhi kinerja karyawan dan pembelajaran, diilustrasikan pada gambar Faktor mempengaruhi kinerja \& pembelajaran.

Kreitner dan Kinicki (2008: 245) mengungkapkan pengaruh Kompetensi terhadap Pembelajaran.

\section{e. Pengaruh Kompetensi terhadap Kinerja}

Robbins dan Judge (2009:99) menyebutkan bahwa: "Kompetensi secara langsung mempengaruhi tingkat kinerja dan kepuasan karyawan melalui kesesuaian kompetensi dan pekerjaan.

Colquitt, LePine dan Wesson (2011:357) mengungkapkan bahwa: "Kompetensi Kognitif, memiliki pengaruh yang kuat secara positif terhadap Kinerja Tugas.

Ivancevich, Konopaske dan Matteson(2008:137) mengungkapkan bahwa: "Sejumlah faktor mempengaruhi kinerja pekerjaan: Ketrampilan dan kompetensi, persepsi, sikap, dan karakteristik kepribadian merupakan contoh-contoh perbedaan individu yang memainkan peran dalam pembentukan kinerja.

\section{f. Sintesis Kompetensi}

Dari uraian di atas, maka yang dimaksud dengan Kompetensi adalah penguasaan terhadap seperangkat pengetahuan, keterampilan, nilai-nilai dan sikap yang 
mengarah kepada kinerja dan diaplikasikan dalam kebiasaan berfikir dan bertindak sesuai dengan tugasnya, dengan indikator: pengetahuan, keterampilan, inisiatif, pemecahan masalah, dan kemampuan beradaptasi.

\section{Budaya Organisasi}

\section{a. Pengertian Budaya Organisasi.}

Schein (2004:17), mendefinisikan "budaya organisasi adalah pola asumsi dasar yang diciptakan, ditemukan, atau dikembangkan oleh kelompok tertentu saat mereka belajar menghadapi masalah adaptasi eksternal dan integrasi internal, yang telah bekerja cukup baik serta dianggap berharga, dan oleh karena itu, diajarkan kepada anggota baru sebagai cara yang benar untuk berpersepsi, berfikir dan merasakan hubungan dengan masalah tersebut.

Menurut Robbins dan Judge (2009:585), Budaya organisasi mengacu pada sebuah sistem makna bersama yang dianut oleh para anggota yang membedakan organisasi tersebut dengan organisasi lainnya.

\section{b. Dimensi Budaya Organisasi}

Robbins dan Judge (2009:511-512) menyebutkan bahwa ada tujuh karakteristik utama yang secara keseluruhan merupakan hakikat budaya sebuah organisasi, meliputi: 1) inovasi dan keberanian mengambil risiko, 2)perhatian pada hal-hal rinci, 3)orientasi hasil, 4)orientasi orang, 5)orientasi tim, 6)keagresifan, \& 7)stabilitas.

Colquit, LePine dan Wesson (2011:574) mengemukakan dimensi budaya organisasi, meliputi: 1)solidaritas, 2) keramah-tamahan 3)pelayanan pelanggan, 4)keselamatan kerja, 5) keaneka ragaman, dan 6)kreativitas.

Menurut Gibson et.al. (2004:33), dimensi budaya organisasi meliputi: 1)integritas, 2) inovasi, 3) menghargai orang, 4) Fokus Pelanggan 5)Tim Kerja, 6)Kepemimpinan, 7) Kinerja dan 8)Komunitas.

\section{c. Fungsi Budaya Organisasi.}

Kreitner \& Kinicki (2008: 70-71) mengungkapkan, Fungsi Budaya Organisasi:

1) Memberikan identitas organisasi kepada karyawannya,

2) Memudahkan komitmen kolektif,

3) Mempromosikan stabilitas sistem sosial,

4) Membentuk perilaku dengan membantu manajer merasakan keberadaannya.

Menurut Robbins dan Judge (2009:589), Fungsi Budaya organisasi meliputi:

1) Berperan sebagai penentu batas-batas, artinya budaya menciptakan perbedaan atau distingsi antara satu organisasi dengan organisasi lainnya,

2) Memuat rasa identitas anggota organisasi,

3) Budaya memfasilitasi lahirnya komitmen sesuatu yang lebih besar daripada kepentingan individu,

4) Budaya meningkatkan stabilitas sistem sosial, 
5) Budaya bertindak sebagai mekanisme sense-making serta kendali yang menuntun dan membentuk sikap dan perilaku karyawan.

\section{d. Pengaruh Budaya Organisasi terhadap Pembelajaran.}

Menurut Noe, et. al. (2008:268), terdapat pengaruh nilai-nilai di dalam budaya organisasi terhadap proses pembelajaran.

Kreitner dan Kinicki (2008:245), mengungkapkan pengaruh Budaya Organisasi terhadap Pembelajaran.

\section{e. Pengaruh Budaya Organisasi terhadap Kinerja}

Noe et.al.(2008:345), menyebutkan:

Budaya Organisasi berpengaruh langsung terhadap kinerja.

Kreitner dan Kinicki (2008:481) mengungkapkan budaya organisasi berpengaruh langsung terhadap peningkatan kinerja individu, kelompok dan organisasi.

\section{e. Sintesis Budaya Organisasi}

Dari uraian di atas, maka yang dimaksud dengan Budaya organisasi adalah satu wujud pola asumsi dasar yang diciptakan, ditemukan, atau dikembangkan dalam suatu organisasi sebagai sistem makna bersama, dianggap berharga, dan dianut oleh para anggota yang membedakan organisasi tersebut dengan organisasi lainnya, dengan indikator: keramah-tamahan, solidaritas, inovasi, kreativitas, dan orientasi hasil.

\section{Pembelajaran}

\section{a. Pengertian Pembelajaran}

Colquitt, LePine \& Wesson (2011:259), mendefinisikan: "pembelajaran adalah perubahan permanen relatif pada pengetahuan atau keahlian karyawan yang dihasilkan dari pengalaman".

Menurut

Noe,et.al.(2008:267),

"Pembelajaran secara terus menerus adalah sistem pembelajaran yang mensyaratkan para karyawan untuk memahami seluruh proses pekerjaan dan mengharapkannya untuk memperoleh keterampilan-keterampilan yang baru dan menerapkannya ke dalam pekerjaan, dan berbagi hal-hal yang telah mereka pelajari dengan karyawan lainnya.

\section{b. Dimensi Pembelajaran}

Menurut Kreitner dan Kinicki (2008:502), dimensi Pembelajaran meliputi: 1)Kreativitas, 2) Ide baru, 3)Menciptakan pengetahuan baru, 4)Informasi baru, 5)Transfer pengetahuan, 6) Perubahan perilaku 7)Penyebaran Pengetahuan baru dan 8)Wawasan baru.

Colquitt, LePine dan Wesson (2011:260), menyampaikan: "dimensi pembelajaran adalah 1) Kreativitas, 2)Ide baru, Menciptakan pengetahuan baru, 4)Informasi baru, 5) Transfer pengetahuan, 6)Perubahan perilaku 7)Penyebaran Pengetahuan baru dan 8)Komunikasi. 
Mathis \& Jackson (2006:306-312), menyatakan bahwa: "Bekerja dalam organisasi haruslah menjadi proses pembelajaran yang berkelanjutan, dan pembelajaran adalah fokus dari semua aktivitas pelatihan. Pelatihan adalah strategis jika; 1)mengembangkan kapabilitas mendasar dari para pekerja, 2)mendorong kemampuan beradaptasi pada perubahan, 3)memajukan pembelajaran berkelanjutan dalam organisasi, 4)menciptakan pengetahuan baru, 5)menyebarkan pengetahuan baru di seluruh organisasi, dan 6) memfasilitasi komunikasi dan 7) fokus.

\section{c. Organisasi Pembelajaran}

Kreitner dan Kinicki (2008:502), mendefinisikan bahwa: Organisasi pembelajaran adalah organisasi yang proaktif menciptakan, memperoleh, dan mentransfer pengetahuan dan perubahan perilaku atas dasar pengetahuan dan wawasan baru.

Menurut Mondy (2008:164), Organisasi pembelajaran adalah suatu perusahaan yang menyadari pentingnya pelatihan dan pengembangan yang terkait dengan kinerja berkelanjutan dan mau mengambil tindakan yang tepat.

\section{d. Pengaruh Pembelajaran terhadap Kinerja \\ Menurut Colquitt, LePine dan Wesson} (2011:279), pembelajaran memiliki pengaruh positif terhadap kinerja. Karyawan yang memperoleh lebih banyak pengetahuan dan keahlian cenderung untuk memiliki tingkat kinerja tugas yang lebih tinggi.

Noe et.al. (2008:268), mengungkapkan pelatihan strategis dan proses pengembangan sebagai dasar pembelajaran karyawan berpengaruh langsung terhadap peningkatan kinerja karyawan.

\section{e. Sintesis Pembelajaran}

Dari uraian di atas, yang dimaksud dengan Pembelajaran adalah setiap perubahan perilaku yang relatif permanen, terjadi sebagai hasil dari pengalaman secara terus menerus dalam memperoleh pengetahuan dan berbagai keterampilan untuk memahami dan menerapkannya dalam seluruh proses pekerjaan, dengan indikator: kreativitas, dorongan perubahan, pembelajaran berkelanjutan, penyebaran pengetahuan baru, dan pengembangan kapabilitas.

\section{B. Kerangka Berpikir}

Penelitian ini bertujuan untuk mengukur pengaruh Kompetensi, Budaya Organisasi, dan proses Pembelajaran terhadap Kinerja Anggota Personel Skadron Teknik 021 Lanud Halim Perdanakusuma. Hubungan pengaruh dari satu variabel searah terhadap variabel yang lainnya, diilustrasikan pada gambar 2.3., sebagai berikut: 


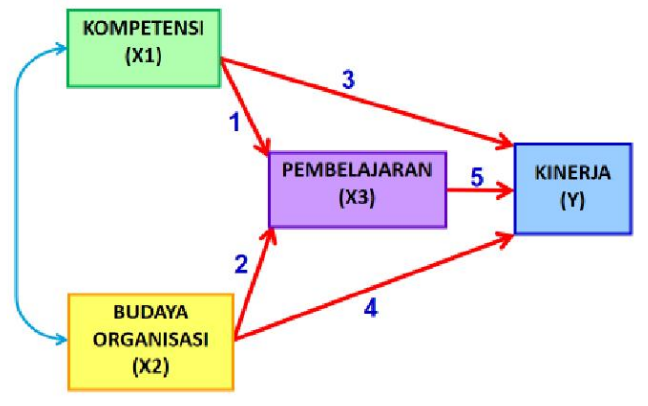

Gambar 2.2. Kerangka berpikir Penelitian

Dari gambar kerangka berpikir tersebut hubungan pengaruh masing-masing variabel dapat dibahas sebagai berikut:

1. Pengaruh Kompetensi terhadap Pembelajaran.

2. Pengaruh Budaya Organisasi terhadap Pembelajaran.

3. Pengaruh Kompetensi terhadap Kinerja.

4. Pengaruh Budaya Organisasi terhadap Kinerja.

5. Pengaruh Pembelajaran terhadap Kinerja

\section{Hipotesis Penelitian}

1. Terdapat pengaruh secara positif Kompetensi terhadap Pembelajaran anggota Skadron Teknik 021.

2. Terdapat pengaruh secara positif Budaya Organisasi terhadap Pembelajaran anggota Skadron Teknik 021.

3. Terdapat pengaruh secara positif Kompetensi terhadap Kinerja anggota Skadron Teknik 021.

4. Terdapat pengaruh secara positif Budaya Organisasi terhadap kinerja anggota Skadron Teknik 021.
5. Terdapat pengaruh secara positif Pembelajaran terhadap Kinerja anggota Skadron Teknik 021.

\section{METODOLOGI PENELITIAN}

\section{A. Tujuan Penelitian}

Penelitian ini secara umum bertujuan untuk mendapatkan data empirik, fakta, dan informasi yang shahih (valid) dan benar, serta dapat dipercaya (reliabel) tentang pengaruh Kompetensi, Budaya Organisasi, dan Pembelajaran terhadap Kinerja Anggota Skadron Teknik 021.

\section{B. Tempat dan waktu penelitian}

Penelitian dilakukan di Skadron Teknik 021 Lanud Halim Perdanakusuma Jakarta, mulai bulan Juli sampai dengan bulan November tahun 2017, meliputi kegiatan pra survey, konsolidasi, uji coba instrumen, uji validitas dan reliabilitas instrumen, serta pengumpulan dan pengolahan data hasil penelitian.

\section{Metode Penelitian}

Penelitian ini menggunakan pendekatan penelitian kuantitatif, dengan menggunakan metode survey (survey research) yaitu penelitian yang bertujuan untuk mengetahui dan menentukan kedudukan sesaat variabel (status quo variable) berdasarkan data yang ada pada saat penelitian dan hubungan antara variabel-variabel yang diteliti. Pemilihan metode ini didasarkan pada pertimbangan 
bahwa penelitian mencakup empat variabel dengan data berasal dari responden yang sama dan menjawab setiap pertanyaan yang diajukan secara serentak dan sekaligus.

Konstelasi hubungan dari empat variabel penelitian, yaitu fungsi kinerja, kompetensi, budaya organisasi dan pembelajaran, dapat diformulasikan dalam bentuk konstelasi masalah penelitian seperti pada gambar berikut:

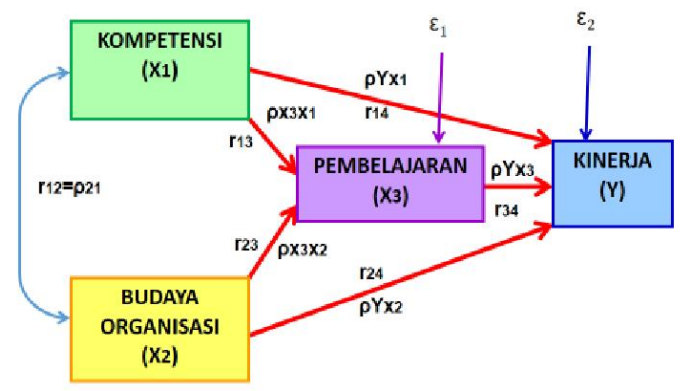

Gambar 3.1. Konstelasi Masalah Penelitian

\section{Populasi dan Sampel}

Populasi penelitian ini adalah seluruh anggota Skadron Teknik 021 Lanud Halim Perdanakusuma Jakarta. Sedangkan populasi homogen dan berkarakter sama dalam penelitian ini adalah seluruh anggota berpangkat bintara dan tamtama yang berjumlah 173 orang.

Sampel penelitian ini adalah seluruh populasi yang terjangkau dan berkarakter sama yang memenuhi syarat penelitian.

Populasi yang memenuhi syarat penelitian ini adalah (1) perwira, (2) bintara inspektor, (3) bintara flight engineer, (4)bintara mekanik, (5) tamtama mekanik, yang sehari-hari bekerja dan berlokasi di Skadron Teknik 021 Lanud Halim Perdanakusuma Jakarta.

\section{E. Teknik Pengumpulan Data}

Penelitian ini menggunakan data primer yang dikumpulkan melalui kuesioner sebagai instrumen penelitian. Kuesioner disampaikan kepada responden yaitu anggota Skadron Teknik 021 berpangkat bintara dan tamtama yang diteliti. Untuk melengkapi hasil kuesioner tersebut, dilakukan wawancara terhadap informan yang tidak ditentukan secara ketat, tetapi disesuaikan dengan keterkaitan data dan informasi yang dibutuhkan.

Dalam penelitian ini jenis data yang dikumpulkan adalah data faktual khusus dalam mengukur kinerja yang merupakan data kualitatif yang dikuantitatifkan, dan variabel-variabel yang diduga mempengaruhinya, yaitu kompetensi, budaya organisasi dan pembelajaran.

Instrumen penelitian yang digunakan dalam penelitian ini adalah kuesioner kompetensi, budaya organisasi pembelajaran dan kinerja.

Setiap instrumen dilengkapi dengan tujuan pengukuran, petunjuk pengisian dan skala penilaian. Untuk kuesioner kompetensi, budaya organisasi, dan pembelajaran, diisi oleh responden yaitu anggota berpangkat bintara dan tamtama, sedangkan kuesioner 
kinerja yang merupakan penilaian kinerja, diisi oleh atasan responden. Untuk menghindari terjadinya salah pasangan terhadap penilaian maka diberikan kode penomoran responden.

Instrumen penelitian dalam penelitian ini diuraikan berdasarkan variabel-variabel penelitian, sebagai berikut:

\section{Variabel Kinerja}

\section{a. Definisi Operasional}

Kinerja adalah hasil pekerjaan seorang anggota Skadron Teknik 021 dalam melaksanakan tugas sesuai bidangnya dengan indikator: 1) kuantitas, 2)kualitas, 3) ketepatan waktu, 4)pencapaian tujuan, dan 5)kemampuan bekerjasama.

\section{b. Instrumen Final}

Berdasarkan hasil uji validitas dan perhitungan reliabilitas melalui SPSS 20 dan Excel, terhadap kuesioner variabel Kinerja yang terdiri dari 5 indikator dengan 30 butir pertanyaan, semua butir valid dan reliabel, maka semua butir pertanyaan dipakai dalam kuesioner penelitian

\section{Variabel Kompetensi}

\section{a. Definisi Operasional}

Kompetensi adalah penguasaan terhadap seperangkat pengetahuan, keterampilan, nilainilai dan sikap anggota Skadron Teknik 021 Lanud Halim Perdanakusuma yang mengarah kepada kinerja dan diaplikasikan dalam kebiasaan berpikir dan bertindak sesuai dengan bidang tugasnya, dengan indikator: 1) pengetahuan, 2) keterampilan, 3) inisiatif, 4) pemecahan masalah, dan 5) kemampuan beradaptasi.

\section{b. Instrumen Final}

Berdasarkan hasil uji validitas dan perhitungan reliabilitas melalui SPSS 20 dan Excel, terhadap kuesioner variabel Kompetensi yang terdiri dari 5 indikator dengan 30 butir pertanyaan, semua butir valid dan reliabel, maka semua butir pertanyaan dipakai dalam kuesioner penelitian.

\section{Variabel Budaya Organisasi}

\section{a. Definisi Operasional}

Budaya organisasi adalah satu wujud pola asumsi dasar yang diciptakan, ditemukan atau dikembangkan di Skadron Teknik 021 sebagai sistem makna bersama, dianggap berharga dan dianut oleh anggota sesuai bidang tugasnya yang membedakan dengan organisasi lainnya, dengan indikator: 1)keramah-tamahan, 2)solidaritas, 3)inovasi, 4) kreativitas, dan 5) orientasi hasil.

\section{b. Instrumen Final}

Berdasarkan hasil uji validitas dan perhitungan reliabiltas melalui SPSS 20 dan Excel, terhadap kuesioner Budaya Organisasi yang terdiri dari 5 indikator dengan 30 butir pertanyaan, semua butir valid dan reliabel, 
maka semua butir pertanyaan dipakai dalam kuesioner penelitian.

\section{Variabel Pembelajaran}

\section{a. Definisi Operasional}

Pembelajaran adalah setiap perubahan perilaku yang relatif permanen dari seorang anggota yang mempunyai tugas sesuai bidangnya, terjadi sebagai hasil dari pengalaman secara terus menerus dalam memperoleh pengetahuan dan berbagai keterampilan untuk memahami dan menerapkannya dalam seluruh proses pekerjaannya, dengan indikator: 1) kreativitas, 2) dorongan perubahan, 3) pembelajaran berkelanjutan, 4) penyebaran pengetahuan baru, dan 5)pengembangan kapabilitas.

\section{b. Instrumen Final}

Berdasarkan hasil uji validitas dan perhitungan reliabilias melalui SPSS 20 dan Excel terhadap kuesioner variabel pembelajaran yang terdiri dari 5 indikator dengan 30 butir pertanyaan, semua butir valid dan reliabel, maka semua butir pertanyaan dipakai dalam kuesioner penelitian.

\section{F. Teknik Analisis Data}

Untuk keperluan menganalisis data yang telah dikumpulkan, digunakan teknik analisis data secara deskriptif dan inferensial. Penggunaan teknik analisis data secara deskriptif untuk memperoleh gambaran karakteristik penyebaran nilai setiap variabel yang diteliti. Analisis deskriptif digunakan dalam hal penyajian data, ukuran sentral, dan ukuran penyebaran. Penyajian data menggunakan daftar distribusi dan histogram. Ukuran sentral meliputi mean, median, dan modus. Ukuran penyebaran meliputi varians dan simpangan baku.

Analisis inferensial digunakan untuk menguji hipotesis dengan menggunakan analisis jalur (path analysis). Semua pengujian hipotesis dilakukan dengan menggunakan $\alpha=0,05$. Sebelum dilakukan pengujian hipotesis, terlebih dahulu dilakukan uji normalitas galat taksiran regresi dengan menggunakan teknik Liliefors, dan uji homogenitas varians dengan menggunakan teknik Uji Barlett.

Untuk menghitung pengaruh langsung dan tidak langsung dari variabel bebas terhadap suatu variabel terikat, tercermin dari koefisien jalur. Sedangkan untuk menentukan koefisien jalur diperlukan persyaratan sebagai berikut: 1) hubungan antara tiap dua variabel harus merupakan hubungan yang linier, aditif dan kausal; 2)sistem menganut prinsip rekursif (eka arah); 3) semua variabel residu tidak saling berkorelasi dan juga tidak berkorelasi dengan variabel penyebab; dan 4) data masing-masing variabel adalah kontinum.

\section{G. Hipotesis Statistik}

Hipotesis statistik terdiri dari 5:

1. Hipotesis Statistik 1 


$$
\mathrm{H}_{0}: \rho_{31}=0 \quad \mathrm{H}_{1}: \rho_{31}>0
$$

2. Hipotesis Statistik 2

$$
H_{0}: \rho_{32}=0 \quad H_{1}: \rho_{32}>0
$$

3. Hipotesis Statistik 3

$$
\mathrm{H}_{0}: \rho_{\mathrm{Y} 1}=0 \quad \mathrm{H}_{1}: \rho_{\mathrm{Y} 1}>0
$$

4. Hipotesis Statistik 4

$$
\mathrm{H}_{0}: \rho_{\mathrm{Y} 2}=0 \quad \mathrm{H}_{1}: \rho_{\mathrm{Y} 2}>0
$$

5. Hipotesis Statistik 5

$$
\mathrm{H}_{0}: \rho_{\mathrm{Y} 3}=0 \quad \mathrm{H}_{1}: \rho_{\mathrm{Y} 3}>0
$$

Keterangan:

$\mathrm{H}_{0}$ : Hipotesis nol

$\mathrm{H}_{1}$ : Hipotesis alternatif

$\rho_{31}$ : Koefisien Jalur (rho) untuk populasi tentang pengaruh Kompetensi $\left(\mathrm{X}_{1}\right)$ terhadap Pembelajaran $\left(\mathrm{X}_{3}\right)$

$\rho_{32}$ : Koefisien Jalur (rho) untuk populasi tentang pengaruh Budaya organisasi $\left(\mathrm{X}_{2}\right)$ terhadap Pembelajaran $\left(\mathrm{X}_{3}\right)$

$\rho_{Y 1}$ : Koefisien Jalur (rho) untuk populasi tentang pengaruh Kompetensi $\left(\mathrm{X}_{1}\right)$ terhadap Kinerja (Y)

$\rho_{\text {Y2 }}$ : Koefisien Jalur (rho) untuk populasi tentang pengaruh Budaya organisasi $\left(\mathrm{X}_{2}\right)$ terhadap Kinerja (Y)

$\rho_{Y 3}:$ Koefisien Jalur (rho) untuk populasi tentang pengaruh Pembelajaran $\left(\mathrm{X}_{3}\right)$ terhadap Kinerja (Y)

\section{HASIL PENELITIAN DAN PEMBAHASAN}

\section{A. Deskripsi Data}

Deskripsi data penelitian dimaksudkan untuk memberikan gambaran tentang perolehan data hasil penyebaran instrumen penelitian melalui kuesioner. Dalam mendeskripsikan data digunakan perhitungan statistik deskriptif, yaitu meliputi skor minimal, skor maksimal, jangkauan, ratarata, nilai tengah, median, simpangan baku, dan varians. Deskripsi data dilengkapi dengan tabel distribusi frekuensi dan histogram.

\section{Variabel Kinerja}

Distribusi frekuensi dapat digambarkan dalam bentuk histogram sebagai berikut:

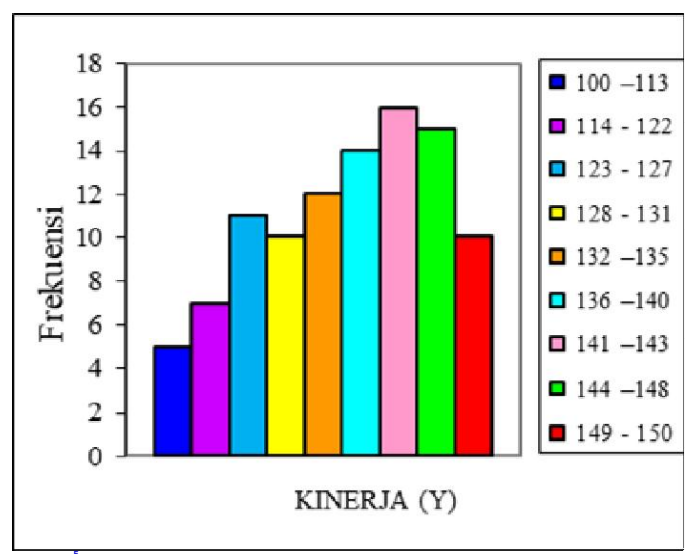

Gambar 4.1. Diagram sebaran skor data Kinerja

\section{Variabel Kompetensi}

Distribusi frekuensi dapat digambarkan dalam bentuk histogram sebagai berikut:

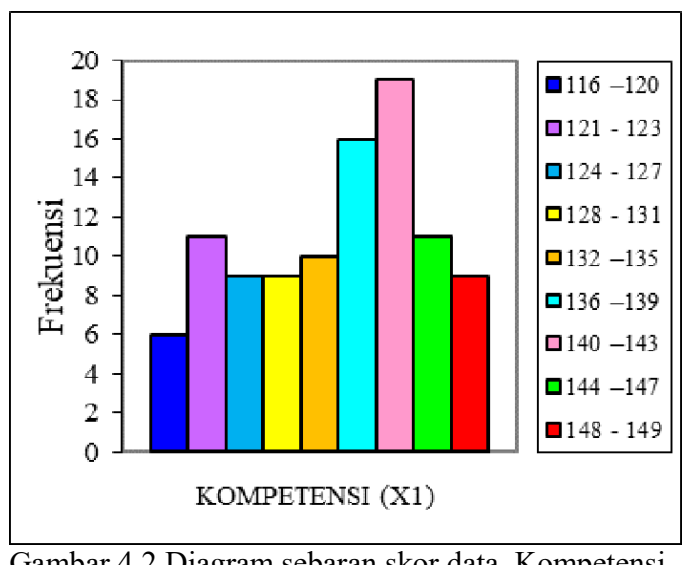

Gambar 4.2.Diagram sebaran skor data Kompetensi 


\section{Variabel Budaya Organisasi}

Distribusi frekuensi dapat digambarkan dalam bentuk histogram sebagai berikut:

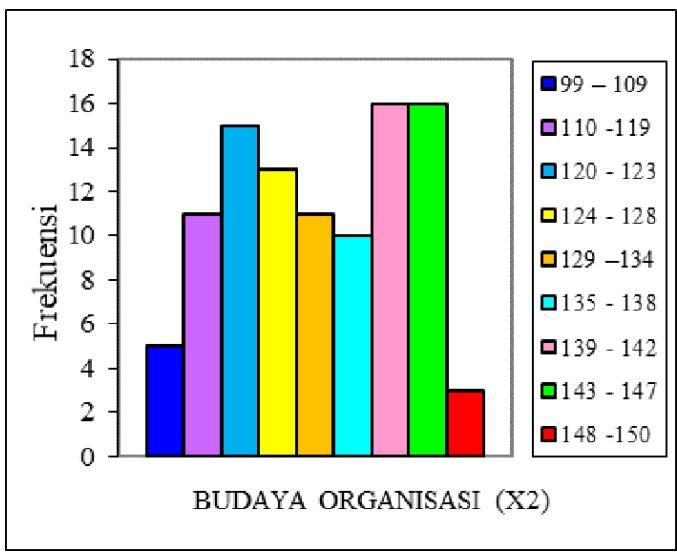

Gambar 4.3.Diagram sebaran skor data Budaya Organisasi

\section{Variabel Pembelajaran}

Distribusi frekuensi dapat digambarkan dalam bentuk histogram sebagai berikut:

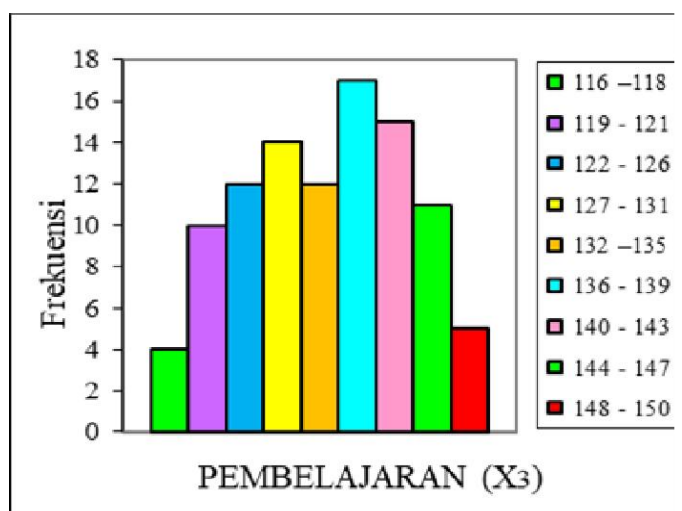

Gambar 4.4. Diagram sebaran skor data Pembelajaran

Deskripsi data penelitian yang dihasilkan

untuk semua variabel dalam penelitian ini, meliputi: Kinerja (Y), Kompetensi $\left(\mathrm{X}_{1}\right)$, Budaya Organisasi $\left(\mathrm{X}_{2}\right)$, dan Pembelajaran $\left(\mathrm{X}_{3}\right)$, disajikan pada table 4.1, berikut ini :

Tabel 4.1. Ringkasan Deskripsi Data 4 variabel

\begin{tabular}{|c|c|c|c|c|}
\hline \multicolumn{5}{|c|}{ Statistics } \\
\hline & $\mathrm{Y}$ & $\mathrm{X}_{1}$ & $\mathrm{X}_{2}$ & $\mathrm{X}_{3}$ \\
\hline Valid & 100 & 100 & 100 & 100 \\
\hline N $\quad$ Missing & 0 & 0 & 0 & 0 \\
\hline Mean & 135.22 & 135.19 & 131.03 & 133.79 \\
\hline Median & 138.00 & 137.00 & 133.00 & 134.50 \\
\hline
\end{tabular}

\begin{tabular}{l|r|r|r|r|} 
Mode & 149 & $143^{\mathrm{a}}$ & 147 & 142 \\
Std. Deviation & 11.155 & 9.220 & 11.892 & 9.268 \\
Variance & 124.436 & 85.004 & 141.423 & 85.905 \\
Skewness & -.888 & -.325 & -.533 & -.127 \\
Kurtosis & .421 & -1.081 & -.253 & -.997 \\
Range & 50 & 33 & 51 & 34 \\
Minimum & 100 & 116 & 99 & 116 \\
Maximum & 150 & 149 & 150 & 150 \\
Sum & 13522 & 13519 & 13103 & 13379 \\
a. Multiple modes exist. The smallest value is shown
\end{tabular}

\section{B. Pengujian Persyaratan Analisis}

Pengujian Persyaratan dalam penelitian, meliputi: 1) Uji Normalitas, 2) Uji Homogenitas, dan 3) Uji Linieritas. Pengujian untuk masing-masing tersebut diatas, disajikan sebagai berikut:

\section{Uji Normalitas}

Uji Normalitas setiap variabel menggunakan SPSS 20 dengan menggunakan Kolmogorov-Smirnov Test. Hasil uji normalitas variabel Kinerja, Kompetensi, Budaya Organisasi, dan Pembelajaran, dalam penelitian ini disajikan pada tabel 4.2.

Tabel 4.2. Hasil Uji Normalitas 4 variabel

Tests of Normality
\begin{tabular}{|l|r|r|r|r|r|r|}
\hline & \multicolumn{3}{|c|}{ Kolmogorov-Smirnov } & \multicolumn{3}{c|}{ Shapiro-Wilk } \\
\cline { 2 - 7 } & Statistic & \multicolumn{1}{c|}{ df } & Sig. & Statistic & df & \multicolumn{1}{c|}{ Sig. } \\
\hline Y & .123 & $\mathbf{1 0 0}$ & .001 & .931 & 100 & .000 \\
X1 & .106 & 100 & .008 & .943 & 100 & .000 \\
X2 & .102 & 100 & .012 & .951 & 100 & .001 \\
X3 & .097 & 100 & .021 & .969 & 100 & .018 \\
\hline
\end{tabular}

a. Lilliefors Significance Correction

Uji Normalitas ke-empat variabel tersebut menunjukkan bahwa data tersebar secara normal. Hal ini dapat ditunjukkan dari nilai signifikansi yang diperoleh seluruhnya lebih kecil dari 0.05 .

Berdasarkan pada hasil tersebut dapat disimpulkan bahwa ke-empat variabel 
tersebut telah memenuhi kriteria uji normalitas.

\section{Uji Homogenitas}

Uji Homogenitas regresi antar variabel dilakukan dengan SPSS 20, dengan hasil, sebagai berikut:

a. Uji Homogenitas Kompetensi terhadap Pembelajaran

Test of Homogeneity of Variances KOMPETENSI - PEMBELAJARAN

\begin{tabular}{|l|l|l|l|}
\hline Levene Statistic & df1 & df2 & Sig. \\
\hline
\end{tabular}

\begin{tabular}{|l|l|l|l|}
\hline 5.827 & 22 & 69 & $\mathbf{. 0 0 0}$ \\
\hline
\end{tabular}

b. Uji Homogenitas Budaya Organisasi terhadap Pembelajaran

Test of Homogeneity of Variances

B.ORGANISASI - PEMBELAJARAN

\begin{tabular}{|c|c|c|c|}
\hline Levene Statistic & df1 & df2 & Sig. \\
\hline 2.992 & 24 & 64 & $\mathbf{. 0 0 0}$ \\
\hline
\end{tabular}

c. Uji Homogenitas Kompetensi terhadap

Kinerja

Test of Homogeneity of Variances

KOMPETENSI - KINERJA

\begin{tabular}{|l|l|l|l|}
\hline Levene Statistic & df1 & df2 & Sig. \\
\hline
\end{tabular}

\begin{tabular}{|l|l|l|l|}
\hline 2.587 & 27 & 66 & $\mathbf{. 0 0 1}$ \\
\hline
\end{tabular}

d. Uji Homogenitas Budaya Organisasi terhadap Kinerja

Test of Homogeneity of Variances

B.ORGANISASI - KINERJA

\begin{tabular}{|r|r|r|c|}
\hline Levene Statistic & df1 & df2 & Sig. \\
\hline 6.453 & 24 & 63 & $\mathbf{. 0 0 0}$ \\
\hline
\end{tabular}

e. Uji Homogenitas Pembelajaran terhadap Kinerja

Test of Homogeneity of Variances PEMBELAJARAN - KINERJA

\begin{tabular}{|r|r|r|r|}
\hline Levene Statistic & \multicolumn{1}{c|}{ df1 } & \multicolumn{1}{c|}{ df2 } & \multicolumn{1}{c|}{ Sig. } \\
\hline 3.411 & 25 & 65 & $\mathbf{. 0 0 0}$ \\
\hline
\end{tabular}

Uji Homogenitas Varians ke-empat variabel, Kompetensi, Budaya Organisasi, dan Pembelajaran terhadap variabel Kinerja tidak signifikan, karena adanya Homogenitas. Ini ditunjukkan dengan nilai signifikansi lebih kecil dari 0.05, sehingga skor-skor pada variabel Kompetensi, Budaya Organisasi, Pembelajaran dan skor-skor pada variabel Kinerja menyebar secara homogen, berarti telah memenuhi kriteria uji Homogenitas.

\section{Uji Linieritas}

Uji Linieritas antar variabel dengan proses ANOVA berdasarkan SPSS 20, jika nilai Linearity < nilai a (0.05), maka distribusi berpola linier.

Hasil Uji Linieritas, sebagai berikut:

a. Uji Linieritas Kompetensi terhadap Pembelajaran $=\mathbf{0 , 0 0 0}$

b. Uji Linieritas Budaya Organisasi terhadap Pembelajaran $=\mathbf{0 , 0 0 0}$

c. Uji Linieritas Kompetensi terhadap Kinerja $=\mathbf{0 , 0 0 0}$

d. Uji Linieritas Budaya Organisasi terhadap Kinerja $=\mathbf{0 , 0 0 0}$

e. Uji Linieritas Pembelajaran terhadap Kinerja $=\mathbf{0 , 0 0 0}$

\section{Pengujian Model}

Sebelum dilakukan perhitungan untuk menguji model kausalitas dengan menggunakan metode analisis jalur, maka diperlukan data hasil penelitian yang telah diuji dan memenuhi seluruh persyaratan. Salah satu persyaratan yang penting dan harus dipenuhi adalah adanya korelasi yang signifikan antara variabel-variabel yang 
terkait. Korelasi antar variabel tersebut dihitung dengan koefisien korelasi.

Berikut ini merupakan langkah-langkah dalam pengujian model, yaitu

\section{Model Struktural dan Matriks Korelasi antar Variabel}

Model struktural dalam penelitian ini disajikan pada gambar 4.5

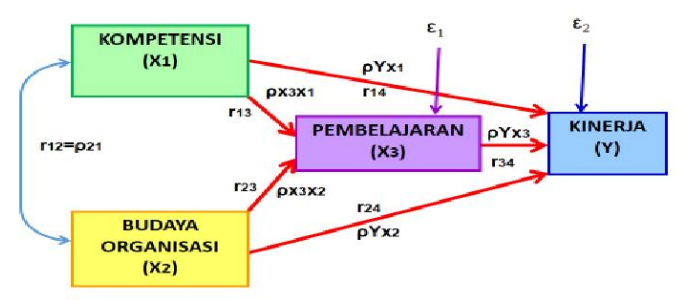

Gambar 4.5. Hubungan kausal; $\mathrm{X}_{1}, \mathrm{X}_{2}$, dan $\mathrm{X}_{3}$ terhadap Y

Tabel 4.3. Matriks Korelasi antar Variabel

\begin{tabular}{|c|c|c|c|c|c|}
\hline \multicolumn{6}{|c|}{ Correlations } \\
\hline & & $(\mathrm{Y})$ & $\left(\mathrm{X}_{1}\right)$ & $\left(X_{2}\right)$ & $\left(X_{3}\right)$ \\
\hline \multirow{3}{*}{$\begin{array}{l}\text { KI } \\
(Y)\end{array}$} & $\begin{array}{l}\text { Pearson } \\
\text { Correlation }\end{array}$ & 1 & $.511^{* *}$ & $.465^{* *}$ & $.424^{* *}$ \\
\hline & Sig. (2-tailed) & & .000 & .000 & .000 \\
\hline & $\mathrm{N}$ & 100 & 100 & 100 & 100 \\
\hline \multirow{3}{*}{$\begin{array}{l}\mathrm{KM} \\
\left(\mathrm{X}_{1}\right)\end{array}$} & $\begin{array}{l}\text { Pearson } \\
\text { Correlation }\end{array}$ & $.511^{* *}$ & 1 & $.528^{* *}$ & $.664^{* *}$ \\
\hline & Sig. (2-tailed) & .000 & & .000 & .000 \\
\hline & $\mathrm{N}$ & 100 & 100 & 100 & 100 \\
\hline \multirow{3}{*}{$\begin{array}{l}\text { BO } \\
\left(X_{2}\right)\end{array}$} & $\begin{array}{l}\text { Pearson } \\
\text { Correlation }\end{array}$ & $.465^{\text {** }}$ & $.528^{* *}$ & 1 & $.597^{* *}$ \\
\hline & Sig. (2-tailed) & .000 & .000 & & .000 \\
\hline & $\mathrm{N}$ & 100 & 100 & 100 & 100 \\
\hline \multirow{3}{*}{$\begin{array}{l}\mathrm{PB} \\
\left(\mathrm{X}_{3}\right)\end{array}$} & $\begin{array}{l}\text { Pearson } \\
\text { Correlation }\end{array}$ & $.424^{* *}$ & $.664^{* * *}$ & $.597^{* *}$ & 1 \\
\hline & Sig. (2-tailed) & .000 & .000 & .000 & \\
\hline & $\mathrm{N}$ & 100 & 100 & 100 & 100 \\
\hline
\end{tabular}

Dari tabel 4.3., dapat diketahui bahwa: koefisien korelasi antar variabel $X_{1}$ dan $X_{2}$ adalah $\mathrm{r}_{12}=0.528$, koefisien korelasi antar variabel $X_{1}$ dan $X_{3}$ adalah $r_{13}=0.664$, koefisien korelasi antar variabel $\mathrm{X}_{2}$ dan $\mathrm{X}_{3}$ adalah $\mathrm{r}_{23}=0.597$, koefisien korelasi antar variabel $\mathrm{X}_{1}$ dan $\mathrm{Y}\left(\mathrm{X}_{4}\right)$ adalah $\mathrm{r}_{14}=0.511$, koefisien korelasi antar variabel $\mathrm{X}_{2}$ dan $\mathrm{Y}\left(\mathrm{X}_{4}\right)$ adalah $\mathrm{r}_{24}=0.465$, koefisien korelasi antar variabel $\mathrm{X}_{3}$ dan $\mathrm{Y}\left(\mathrm{X}_{4}\right)$ adalah $\mathrm{r}_{34}=0.424$.

\section{Perhitungan Koefisien Jalur pada Sub-Struktur}

Model struktural yang ditampilkan pada gambar 4.5 di atas terdiri dari dua sub-struktur, yaitu Sub-Struktur-1 dan Sub-Struktur-2.

\section{Perhitungan Koefisien Jalur pada Sub-Struktur 1}

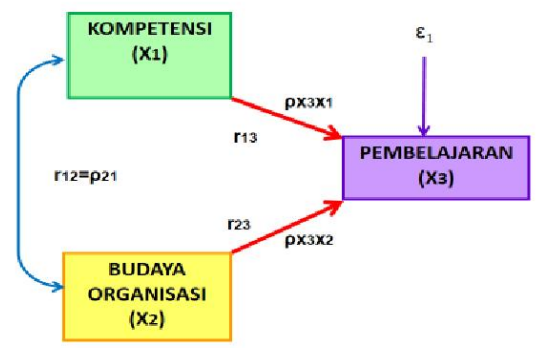

Gambar 4.6. Hubungan kausal: Sub-Struktur 1

Hubungan kausal antar variabel pada SubStruktur-1, yang ditampilkan pada gambar 4.6, terdiri dari satu variabel endogen $\mathrm{X}_{3}$, dan dua variabel eksogen: $\mathrm{X}_{1}$, dan $\mathrm{X}_{2}$.

Persamaan struktural untuk sub-struktur-1 adalah, $X_{3}=\rho x_{3} X_{1} X_{1}+\rho x_{3} X_{2} X_{2}+\varepsilon_{1}$.

Hasil pengolahan data dengan SPSS 20, disajikan pada tabel 4.4, tabel 4.5 dan tabel 4.6., sebagai berikut:

Model 1: Koefisien $X_{1}$,dan $X_{2}$, terhadap Pembelajaran $\left(X_{3}\right)$ Tabel 4.4. Coefficients Model 1 - Sub-Struktur-1

\begin{tabular}{|c|c|c|c|c|c|}
\hline \multirow{3}{*}{ Model } & \multicolumn{3}{|c|}{ Coefficlentsa } & \multirow{3}{*}{$\mathbf{t}$} & \multirow{3}{*}{ Sig. } \\
\hline & \multicolumn{2}{|c|}{$\begin{array}{c}\text { Unstandardized } \\
\text { Coefficients }\end{array}$} & $\begin{array}{r}\text { Standardized } \\
\text { Coefficients } \\
\end{array}$ & & \\
\hline & B & $\begin{array}{c}\text { Std. } \\
\text { Error }\end{array}$ & Beta & & \\
\hline (Constant) & 26.399 & 9.881 & & 2.672 & .009 \\
\hline KOMPETENSI & .278 & .070 & .282 & 3.958 & .000 \\
\hline $\begin{array}{l}\text { BUDAYA } \\
\text { ORGANISASI }\end{array}$ & .536 & .063 & .608 & 8.528 & .000 \\
\hline
\end{tabular}


Model 1: Anova $\mathbf{X}_{1}$, dan $\mathbf{X}_{2}$, terhadap Pembelajaran $\left(\mathbf{X}_{3}\right)$ Tabel 4.5. ANOVA Model 1 - Sub-Struktur-1

\begin{tabular}{|l|l|r|r|r|c|}
\hline Model & $\begin{array}{c}\text { Sum of } \\
\text { Squares }\end{array}$ & df & \multicolumn{1}{c|}{$\begin{array}{c}\text { Mean } \\
\text { Square }\end{array}$} & F & Sig. \\
\hline \multicolumn{1}{|l|}{ Regression } & $\mathbf{4 8 5 4 . 8 3 4}$ & $\mathbf{2}$ & $\mathbf{2 4 2 7 . 4 1 7}$ & $\mathbf{6 6 . 5 9 4}$ & $\mathbf{. 0 0 0}^{\mathrm{b}}$ \\
1 Residual & $\mathbf{3 5 3 5 . 7 5 6}$ & $\mathbf{9 7}$ & $\mathbf{3 6 . 4 5 1}$ & & \\
\multicolumn{1}{|c|}{ Total } & $\mathbf{8 3 9 0 . 5 9 0}$ & $\mathbf{9 9}$ & & & \\
\hline
\end{tabular}

a. Dependent Variable: PEMBELAJARAN

b. Predictors: (Constant), BUDAYA_ORGANISASI, KOMPETENSI

Model 1: Summary $X_{1}$ dan $X_{2}$, terhadap Pembelajaran $\left(X_{3}\right)$ Tabel 4.6. Model Summary Model 1 - Sub-Struktur-1

\begin{tabular}{|l|c|r|r|r|}
\hline Model & R & $\begin{array}{c}\text { R } \\
\text { Square }\end{array}$ & $\begin{array}{r}\text { Adjusted } \\
\text { R Square }\end{array}$ & $\begin{array}{r}\text { Std. Error of } \\
\text { the Estimate }\end{array}$ \\
\hline 1 & $.761^{\text {a }}$ & .579 & .570 & $\mathbf{6 . 0 3 7}$ \\
\hline
\end{tabular}

a. Predictors: (Constant), BUDAYA_ORGANISASI,

KOMPETENSI

b. Dependent Variable: PEMBELAJARAN

\section{Perhitungan Besar Pengaruh pada Sub-Struktur-1}

Untuk mengetahui besarnya pengaruh yang diterima oleh sebuah variabel endogen dari dua variabel eksogen, dapat secara parsial maupun bersama-sama. Pengaruh secara parsial berupa pengaruh langsung, maupun pengaruh tidak langsung, yaitu melalui variabel eksogen yang lain.

a. Menghitung pengaruh langsung, pengaruh tidak langsung, serta pengaruh total variabel Kompetensi $\left(\mathrm{X}_{1}\right)$ terhadap variabel Pembelajaran $\left(\mathrm{X}_{3}\right)$ secara parsial bersama variabel Budaya Organisasi $\left(\mathrm{X}_{2}\right)$ :

1) Besarnya pengaruh langsung variabel $\left(\mathrm{X}_{1}\right)$ terhadap variabel $\left(\mathrm{X}_{3}\right)=\rho \mathrm{X}_{3} \mathrm{X}_{1} \mathrm{x}$ $\rho \mathrm{x}_{3} \mathrm{X}_{1}=0.282 \times 0.282=0.0795=$ $7,95 \%$

2) Besarnya pengaruh tidak langsung variabel $\left(\mathrm{X}_{1}\right)$ terhadap variabel $\left(\mathrm{X}_{3}\right)$, melalui variabel Budaya Organisasi
$\left(\mathrm{X}_{2}\right)=\rho \mathrm{x}_{3} \mathrm{X}_{1} \mathrm{x} \quad \mathrm{rx}_{1} \mathrm{X}_{2} \mathrm{X}_{\rho} \mathrm{x}_{3} \mathrm{X}_{2}=0.282 \mathrm{x}$

$0.528 \times 0.608=0.0905=9,05 \%$

3) Besarnya pengaruh total variabel $X_{1}$ terhadap variabel $\mathrm{X}_{3}$ melalui variabel Budaya Organisasi $\left(\mathrm{X}_{2}\right), \quad=$ $\left[\rho \mathrm{x}_{3} \mathrm{x}_{1} \mathrm{x}_{\rho} \mathrm{x}_{3} \mathrm{x}_{1}\right]+\left[\rho \mathrm{x}_{3} \mathrm{x}_{1} \mathrm{xrx}_{1} \mathrm{x}_{2} \mathrm{x} \rho \mathrm{x}_{3} \mathrm{x}_{2}\right]=$ $0.0795+0.0905=0.17=17 \%$

Kesimpulan : pengaruh variabel Kompetensi $\left(\mathrm{X}_{1}\right)$ terhadap variabel Pembelajaran $\left(X_{3}\right)$ adalah sebesar 17\%, hal ini berarti Pembelajaran ditentukan oleh Kompetensi sebesar $17 \%$.

b.Menghitung pengaruh langsung, pengaruh tidak langsung, serta pengaruh total variabel Budaya Organisasi $\left(\mathrm{X}_{2}\right)$ terhadap variabel Pembelajaran $\left(\mathrm{X}_{3}\right)$ secara parsial bersama variabel Kompetensi $\left(\mathrm{X}_{1}\right)$ : Kesimpulan : pengaruh variabel Budaya Organisasi $\left(\mathrm{X}_{2}\right)$ terhadap variabel Pembelajaran $\left(X_{3}\right)$ adalah sebesar $46,02 \%$, hal ini berarti Pembelajaran ditentukan oleh Budaya Organisasi sebesar 46,02\%.

\section{Perhitungan Koefisien Jalur pada Sub-Struktur-2}

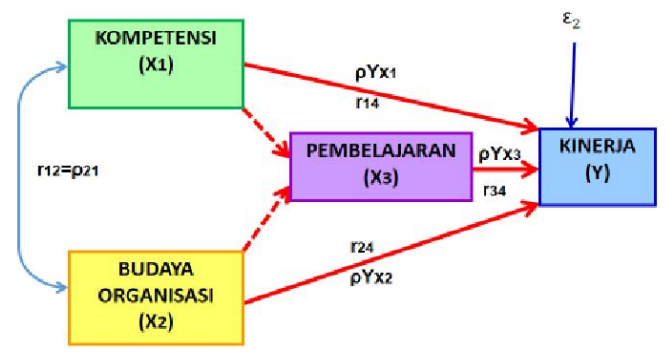

Gambar 4.7. Hubungan kausal: Sub-Struktur 2 
Hubungan kausal antar variabel pada Sub-Struktur-2, yang ditampilkan pada gambar 4.7, terdiri dari 1 variabel endogen yaitu Kinerja (Y) dan 3 variabel eksogen yaitu: 1) Kompetensi ( $\left.\left.\mathrm{X}_{1}\right), 2\right)$ Budaya Organisasi $\left(X_{2}\right)$, dan 3) Pembelajaran $\left(X_{3}\right)$,

Persamaan struktural sub-struktur-2 adalah: $Y=\rho Y_{x_{1}} X_{1}+\rho Y_{2} X_{2}+\rho Y x_{3} X_{3}+\varepsilon_{2}$

Hasil pengolahan data dengan SPSS 20, disajikan pada tabel 4.7 , tabel 4.8 dan tabel 4.9., sebagai berikut:

Model 1: Koefisien $\mathrm{X}_{1}, \mathrm{X}_{2}, \& \mathrm{X}_{3}$ terhadap Kinerja (Y) Tabel 4.7. Coefficients Model 1 - Sub-Struktur-2

\begin{tabular}{|c|c|c|c|c|c|}
\hline \multirow[t]{2}{*}{ Model } & \multicolumn{2}{|c|}{$\begin{array}{l}\text { Unstandardized } \\
\text { Coefficients }\end{array}$} & \multirow{2}{*}{$\begin{array}{c}\begin{array}{c}\text { Standardized } \\
\text { Coefficients }\end{array} \\
\text { Beta }\end{array}$} & \multirow[t]{2}{*}{$t$} & \multirow[t]{2}{*}{ Sig. } \\
\hline & B & $\begin{array}{c}\text { Std. } \\
\text { Error }\end{array}$ & & & \\
\hline (Constant) & .577 & 12.754 & & .045 & .964 \\
\hline KOMPETENSI & .266 & .094 & .223 & 2.825 & .006 \\
\hline $\begin{array}{l}1 \text { BUDAYA- } \\
\text { ORGANISASI }\end{array}$ & .423 & .104 & .396 & 4.082 & .000 \\
\hline PEMBELAJARAN & .326 & .126 & .269 & 2.578 & .011 \\
\hline
\end{tabular}

a. Dependent Variable: KINERJA

Model 1: ANOVA $\mathrm{X}_{1}, \mathrm{X}_{2}, \& \mathrm{X}_{3}$ terhadap Kinerja (Y) Tabel 4.8. ANOVA Model 1 Sub-Struktur-2

\begin{tabular}{|c|c|c|c|c|c|}
\hline \multicolumn{6}{|c|}{ ANOVA $^{\mathbf{a}}$} \\
\hline Model & $\begin{array}{c}\text { Sum of } \\
\text { Squares }\end{array}$ & df & $\begin{array}{c}\text { Mean } \\
\text { Square }\end{array}$ & $\mathbf{F}$ & Sig. \\
\hline $\begin{array}{ll}\text { Regression } \\
1 & \text { Residual } \\
\text { Total }\end{array}$ & $\begin{array}{r}6888.809 \\
5430.351 \\
12319.160\end{array}$ & $\begin{array}{r}3 \\
96 \\
99\end{array}$ & $\begin{array}{r}2296.270 \\
56.566\end{array}$ & 40.594 & $.000^{b}$ \\
\hline
\end{tabular}

BUDAYA_ORGANISASI

Model 1: Summary $X_{1}, X_{2}, \& X_{3}$, terhadap Kinerja (Y) Tabel 4.9. Model Summary Model 1 Sub-Struktur-2 Model Summary

\begin{tabular}{l|r|r|r|r|}
\hline Model & $\mathbf{R}$ & $\begin{array}{c}\mathrm{R} \\
\text { Square }\end{array}$ & $\begin{array}{c}\text { Adjusted } \\
\text { R Square }\end{array}$ & $\begin{array}{c}\text { Std. Error of } \\
\text { the Estimate }\end{array}$ \\
\hline 1 & $.748^{\mathrm{a}}$ & .559 & .545 & 7.521 \\
\hline
\end{tabular}
a. Predictors: (Constant), PEMBELAJARAN,
KOMPETENSI, BUDAYA_ORGANISASI
b. Dependent Variable: KINERJA

\section{Perhitungan Besar Pengaruh pada Sub-Struktur 2}

Untuk mengetahui besarnya pengaruh yang diterima oleh sebuah variabel endogen dari tiga variabel eksogen, dapat secara parsial maupun bersama-sama. Pengaruh secara parsial berupa pengaruh langsung, maupun pengaruh tidak langsung, yaitu melalui variabel eksogen yang lain.

a. Menghitung pengaruh langsung, pengaruh tidak langsung, serta pengaruh total variabel Kompetensi $\left(\mathrm{X}_{1}\right)$ terhadap variabel Kinerja (Y) secara parsial bersama variabel Budaya Organisasi $\left(\mathrm{X}_{2}\right)$, dan variabel Pembelajaran $\left(\mathrm{X}_{3}\right)$ :

1) Besarnya pengaruh langsung variabel $\left(\mathrm{X}_{1}\right)$ terhadap variabel $(\mathrm{Y})=\rho_{\mathrm{YX}} \mathrm{X}_{1} \quad \mathrm{x}$ $\rho \mathrm{Yx}_{1}=0.223 \times 0.223=0.0497=$ $4,97 \%$

2) Besarnya pengaruh tidak langsung variabel $\left(\mathrm{X}_{1}\right)$ terhadap variabel $(\mathrm{Y})$, melalui variabel Budaya Organisasi $\left(\mathrm{X}_{2}\right)=\rho \mathrm{Yx}_{1} \mathrm{x} \quad \mathrm{rx}_{1} \mathrm{x}_{2} \mathrm{x} \rho \mathrm{Yx}_{2}=0.223 \mathrm{x}$ $0.528 \times 0.396=0.0466=4,66 \%$

3) Besarnya pengaruh tidak langsung variabel $\left(\mathrm{X}_{1}\right)$ terhadap variabel $(\mathrm{Y})$, melalui variabel Pembelajaran $\left(\mathrm{X}_{3}\right)$ $=\rho_{\mathrm{Y}} \mathrm{x}_{1} \mathrm{x} \operatorname{rx}_{1} \mathrm{x}_{3} \mathrm{x} \rho \mathrm{Yx}_{3}=0.223 \times 0.664 \mathrm{x}$ $0.269=0.0398=3,98 \%$

4) Besarnya pengaruh total variabel $X_{1}$ terhadap variabel $\mathrm{Y}$ melalui variabel Budaya Organisasi $\left(\mathrm{X}_{2}\right), \quad$ dan Pembelajaran $\left(\mathrm{X}_{3}\right)=\left[\rho \mathrm{Yx}_{1} \mathrm{x} \rho \mathrm{Yx}_{1}\right]+$ $\left[\rho \mathrm{Yx}_{1} \mathrm{xrx}_{1} \mathrm{x}_{2} \mathrm{x} \rho \mathrm{Yx}_{2}\right]+\left[\rho \mathrm{Yx}_{1} \mathrm{xrx}_{1} \mathrm{x}_{3} \mathrm{x} \rho \mathrm{Yx}\right.$ 3] $=0.0497+0.0466+0.0398=$ $0.1361=13,61 \%$ 
Kesimpulan : pengaruh variabel Kompetensi $\left(\mathrm{X}_{1}\right)$ terhadap variabel Kinerja (Y) adalah sebesar $13,61 \%$, hal ini berarti Kinerja ditentukan oleh Kompetensi sebesar $13,61 \%$.

b.Menghitung pengaruh langsung, pengaruh tidak langsung, serta pengaruh total variabel Budaya Organisasi $\left(\mathrm{X}_{2}\right)$ terhadap variabel Kinerja (Y) secara parsial bersama variabel Kompetensi $\left(\mathrm{X}_{1}\right), \quad$ dan Pembelajaran $\left(\mathrm{X}_{3}\right)$ :Kesimpulan : pengaruh variabel Budaya Organisasi $\left(\mathrm{X}_{2}\right)$ terhadap variabel Kinerja (Y) adalah sebesar $\mathbf{2 6 , 7 \%}$, hal ini berarti Kinerja ditentukan oleh Budaya Organisasi sebesar 26,7\%.

c. Menghitung pengaruh langsung, pengaruh tidak langsung, serta pengaruh total variabel Pembelajaran $\left(\mathrm{X}_{3}\right)$ terhadap variabel Kinerja (Y) secara parsial bersama variabel Kompetensi $\left(\mathrm{X}_{1}\right)$, dan Budaya Organisasi $\left(\mathrm{X}_{2}\right)$ :Kesimpulan: pengaruh variabel Pembelajaran $\left(X_{3}\right)$, terhadap variabel Kinerja (Y) adalah sebesar $\mathbf{1 7 , 5 8 \%}$, berarti Kinerja ditentukan oleh Pembelajaran sebesar 17,58\%.

\section{Kesimpulan Pengujian Hipotesis}

Dari kesimpulan yang diperoleh dapat dikomparasikan dengan hipotesis yang diajukan dalam penelitian ini. Dari Lima hipotesis yang diajukan, berdasarkan hasil penelitian, seluruh hipotesis null $\left(\mathrm{H}_{0}\right)$ ditolak dan menerima hipotesis alternatif $\left(\mathrm{H}_{1}\right)$.

\section{1). Hipotesis Pertama}

Hipotesis null $\left(\mathrm{H}_{0}\right)$ ditolak berdasarkan uji keberartian koefisien jalur, nilai hitung $\rho$ untuk variabel Kompetensi $\left(\mathrm{X}_{1}\right)=0.000$ atau $0.000<0.05$. Hal ini berarti secara parsial terdapat pengaruh secara signifikan antara Kompetensi $\left(\mathrm{X}_{1}\right)$ terhadap Pembelajaran $\left(\mathrm{X}_{3}\right)$. Hipotesis satu $\left(\mathrm{H}_{1}\right)$ diterima yaitu: "Terdapat pengaruh Kompetensi terhadap Pembelajaran". Besar pengaruh Kompetensi terhadap Pembelajaran adalah sebesar 17\%.

2) Hipotesis Kedua:Terdapat pengaruh secara positif dan signifikan $(0.000<$ 0.05) variabel Budaya Organisasi terhadap variabel Pembelajaran, sebesar 46,02\%.

3) Hipotesis Ketiga: Terdapat pengaruh secara positif dan signifikan (0.006 < 0.05) variabel Kompetensi terhadap variabel Kinerja, sebesar 13,61\%.

4) Hipotesis Keempat: Terdapat pengaruh secara positif dan signifikan $(0.000<$ $0.05)$ variabel Budaya Organisasi terhadap variabel Kinerja, sebesar 26,7\%.

5) Hipotesis Kelima: Terdapat pengaruh secara positif dan signifikan $(0.011<$ 0.05) variabel Pembelajaran terhadap variabel Kinerja, sebesar 17,58\%.

\section{E. Keterbatasan Penelitian}

Penelitian dengan judul pengaruh Kompetensi, Budaya Organisasi, dan Pembelajaran terhadap Kinerja anggota Skadron Teknik 021, berfokus pada pengujian pengaruh langsung antar variabel 
dalam hubungan kausal yang disajikan dengan sebuah jalur kausalistik. Untuk keperluan ini digunakan analisis jalur dengan dibantu software SPSS 20.0. Namun demikian penelitian ini tidak terlepas dari keterbatasan yang dapat mengakibatkan adanya keterbatasan-keterbatasan pada pengukuran variabel secara akurat, dan masih adanya keterbatasan lain yang mungkin ikut menentukan variabel kinerja, namun tidak diteliti di dalam penelitian ini.

\section{KESIMPULAN, dan IMPLIKASI}

\section{a. Kesimpulan}

Berdasarkan hasil analisis data dan pembahasan hasil penelitian, maka temuan penelitian disimpulkan sebagai berikut:

1. Terdapat pengaruh langsung secara positif dan signifikan Kompetensi terhadap Pembelajaran Anggota Skadron Teknik 021 Lanud Halim Perdanakusuma. Temuan ini dapat diartikan bahwa tinggi rendahnya kualitas Pembelajaran, salah satunya dipengaruhi oleh Kompetensi, sehingga jika kualitas Kompetensi ditingkatkan, akan dapat meningkatkan kualitas Pembelajaran.

2. Terdapat pengaruh langsung secara positif dan signifikan Budaya Organisasi terhadap Pembelajaran Anggota Skadron Teknik 021 Lanud Halim Perdanakusuma. Temuan ini dapat diartikan bahwa tinggi rendahnya kualitas Pembelajaran, salah satunya dipengaruhi oleh Budaya Organisasi, sehingga jika kualitas Budaya Organisasi ditingkatkan, akan dapat meningkatkan kualitas Pembelajaran.

3. Terdapat pengaruh langsung secara positif dan signifikan Kompetensi terhadap Kinerja Anggota Skadron Teknik 021 Lanud Halim Perdanakusuma. Temuan ini dapat diartikan bahwa tinggi rendahnya kualitas Kinerja, salah satunya dipengaruhi oleh Kompetensi, sehingga jika kualitas Kompetensi ditingkatkan, akan dapat meningkatkan kualitas Kinerja.

4. Terdapat pengaruh langsung secara positif dan signifikan Budaya Organisasi terhadap Kinerja Anggota Skadron Teknik 021 Lanud Halim Perdanakusuma. Temuan ini dapat diartikan bahwa tinggi rendahnya kualitas Kinerja, salah satunya dipengaruhi oleh Budaya Organisasi, sehingga jika kualitas Budaya Organisasi ditingkatkan, akan dapat meningkatkan kualitas Kinerja.

5. Terdapat pengaruh langsung secara positif dan signifikan Pembelajaran terhadap Kinerja Anggota Skadron Teknik 021 Lanud Halim Perdanakusuma. Temuan ini dapat diartikan bahwa tinggi rendahnya kualitas Kinerja, salah satunya dipengaruhi oleh Pembelajaran, sehingga jika kualitas Pembelajaran ditingkatkan, akan dapat meningkatkan kualitas Kinerja.

\section{b. Implikasi}

Berdasarkan kesimpulan penelitian di atas, maka diajukan implikasi hasil penelitian ini sebagai berikut: 
1. Untuk meningkatkan kualitas Pembelajaran Anggota Skadron Teknik 021 Lanud Halim Perdanakusuma, diperlukan peningkatan kualitas Kompetensi.

2. Untuk meningkatkan kualitas Anggota Skadron Teknik 021 Lanud Halim Perdanakusuma, diperlukan peningkatan kualitas Budaya Organisasi.

3. Untuk meningkatkan kualitas Kinerja Anggota Skadron Teknik 021 Lanud Halim Perdanakusuma, diperlukan peningkatan kualitas Kompetensi.

4. Untuk meningkatkan kualitas Kinerja Anggota Skadron Teknik 021 Lanud Halim Perdanakusuma, diperlukan peningkatan kualitas Budaya Organisasi.

5. Untuk meningkatkan kualitas Kinerja Anggota Skadron Teknik 021 Lanud Halim Perdanakusuma, diperlukan peningkatan kualitas Pembelajaran.

\section{DAFTAR PUSTAKA}

Chambers, Essential English Dictionary, Edinburgh: Chambers Harrap Publishers Ltd., 1995.

Colquitt, Jason A., Jeffery A. LePine \& Michael J. Wesson, Organi-zational Behavior: Improving Performance and Commitment in the workplace, Second Edition. New York: McGraw-Hill Irwin, 2011
Dessler, Gary, Human Resource Management, Eleventh Edition, New Jersey: Pearson Prentice Hall, 2008

Gibson, James L. et.al., Organizations: Behavior, Structure, Processes, Eleventh Edition, New York: McGraw Hill, International Edition, 2004

Hadari Nawawi, Prof., Dr., Manajemen Sumber Daya Manusia untuk Bisnis yang Kompetitif, Cetakan Ketujuh, Yogyakarta : Gajah Mada University Press, 2008

Ivancevich, John M., Robert Konopaske \& Michael T. Matteson, Organizational Behavior and Management, Eighth Edition, New York: McGraw-Hill International Edition, 2008

Kreitner, Robert \& Angelo Kinicki, Organizational Behavior, Eighth Edition, New York: Mc Graw-Hill/Irwin International, 2008

Luthans, Fred, Organizational Behavior, Twelfth Edition, New York: McGrawHill International Edition, 2011.

Mathis, Robert L \& John H Jackson, Human Resource Management: Manajemen Sumber Daya Manusia, Edisi Sepuluh. Jakarta: Penerbit Salemba Empat, 2006.

Mondy, R. Wayne, Human Re-source Management, Tenth Editi-on, New Jersey: Pearson Prentice -Hill International Edition, 2008.

Noe, Raymond A. et.al., Human Resource Management: Gaining a competitive advantage, Sixth Edition, New York: McGraw-Hill International Edition, 2008. 
Robbins, Stephen P. \& Timothy A. Judge, Organizational Behavior, Thirteenth Edition, New Jersey: Pearson Prentice Hall, 2009.

Sambas Ali Muhidin dan Maman Abdurahman. Analisis Korelasi,Regresi, dan Jalur dalam Penelitian, Cetakan I. Bandung: CV Pustaka Setia, 2009

Schein, Edgar H., Organizational Culture and Leadership, Third Edition, San Francisco: Jossey-Bass A Wiley Imprint, 2004

Soekidjo Notoatmodjo, Prof., Dr., Pengembangan Sumber Daya Manusia, Cetakan Keempat, Jakarta : PT Rineka Cipta, 2009

Wibowo, Manajemen Kinerja, Edisi Kedua, Jakarta: Rajawali Pers, 2012 